\title{
Synthesis of Azo-functionalized Calix[4]arenes and Its Application to Chloride-selective Electrode as Ionophores
}

\author{
Hyo Kyoung Lee, Heekyoung Yeo, Duck Hee Park, and Seungwon Jeon* \\ Department of Chemistry and Institute of Basic Science, Chonnam National Vhiversity. Gwangiu 500-757, Korea \\ Received Mav 9,2003
}

\begin{abstract}
Azo-functionalized calix[4]arenes as ionophores for chloride-selective electrode. 5,11.17.23-Tetra-tert-buty'25.27-bis[(N.N-dimethyl-aniline-azo-phenylthioureido)ethyl]oxy-26.28-dihydroxycalix[4]arene $(4 \mathrm{a})$ and 5.11.17.23-Tetra-tert-butyl-25.27-bis[(N.N-dimethyl-aniline-azo-phenỵlthioureido)ethyl] oxycalix[+]arene $(\boldsymbol{t} \mathbf{b})$ were synthesized. The PVC membrane electrode based on azo-functionalized calix[4]arene ta with o-NPOE exhibits a linear stable response over a wide concentration range $\left(1.5 \times 10^{-4}\right.$ $1.0 \times 10^{-1}$ ) with a slope of $-52.0 \mathrm{mV} /$ decade and a detection limit of $\log \left[\mathrm{Cl}^{-}\right]=-4.02$. This ionophore-based membrane exhibited improved selectivity for chloride anion compared with classical Hofmeister series.
\end{abstract}

Key Words : Azo-functionalized calix[4]arene. $\mathrm{Cl}^{-}-$ISEs, Neutral ionophore

\section{Introduction}

The ligands for complexation of anions need to have comparatively large cavities, which have so far proved difficult to synthesize. Selective complexation of anions is also more dentanding than that of cations a result of the higher free solvation energies of anions. the low charge density of anions. and the $\mathrm{pH}$ dependence of anion complexation. ${ }^{1.2}$ Accompanied by the development of ionselective electrodes (ISEs). the selective determination of many anions has a crucial drawback .. the classical Hofmeister series. which is correlated with a preference for hydrophobic anions. Therefore, the need for ionophores with improved selectivities and sensitivities in the field of anionselective electrodes increases. Several liquid and polymer membrane-based ISEs have been reported for the analysis of the chloride anion ${ }^{3.4}$ Most of the current ISEs applied to clinical clloride determinations are based on an ion-sensing material of an ion-exchanger type, such as quarternary ammonium salts.$^{5-7}$ Basically. the selectivity of an ISE based on such as ion-exchanger is ruled by the lipophilicity of the ion. ${ }^{8}$ Chloride-selective electrodes. the impregnation of lipophilic anions into a plasticized anion-exchange membrane, ${ }^{3}$ an annealed polyion complex membrane. an organic-inorganic hybrid sol-gel natrix ${ }^{11 !}$ all-solid-state electrodes with plasticizerfree membrane. ${ }^{11}$ silicone rubber matrix. ${ }^{12}$ polyurethane mentbranes. ${ }^{13}$ and electropolymerized electrodes ${ }^{1+}$ have been reported to enhance chloride selectivity.

In the present study, we describe the fabrication and characterization of new ISEs based on two azo-functionalized calix[4]arenes as neutral ionophores. Calixarene's structures have received considerable attention as interesting classes of an ionic and molecular binding host. ${ }^{15.16}$ Recently we reported that lower rum urea-functionalized calix[4]diquinones show high selectivity as neutral receptors for $\mathrm{HSO}_{4}{ }^{-17-19}$ and as ionophores for $\mathrm{HSO}_{3}^{-}{ }^{-20}$ The urea and thiourea groups have been used in the development of neutral ionophores, because the hydrogen bond donors can provide the anion binding site selectively. The ISE dynamic response is generated by selective complexation of the target ion with neutral ionophores dispersed in a poly(vinyl chloride) (PVC) matrix. PVC membranes based on azofunctionalized calix[4]arenes are investigated here as $\mathrm{Cl}^{-}$. selective sensing electrodes. When compared with Hofmeister series obtained from the electrode based on a quartennary anmonium salt, the ISE based on azo-functionalized calix[4]arene ta exhibits improved selectivity and longevity for clloride anion.

\section{Experimental Section}

Reagents. Azo-functionalized calix[4]arenes ( $4 a, 4 b)$ tested as chloride ionophores were synthesized. and their synthetic procedure is shown in Fig. 1. High molecular weight PVC, 2-nitrophenyl octyl ether $(o$-NPOE), dioctyl sebacate (DOS), tridodecylmethylammonium chloride (TDDMACl) and tetrahydrofuran (THF). which were obtained from Fluka. were used to prepare the PVC membrane electrodes Analytical grade sodium and potassium salts of tested anions were used. Doubly distilled water in a quartz apparatus was used to prepare all aqueous electrolyte solutions.

Syntheses. 5,11,17,23-Tetra-tert-butyl-25,27-bis(cyanomethyloxy)-26,28-di-hydroxycalix[t]arene (2a). A p-tertbutylcalix[4]arene $(5.0 \mathrm{~g} .7 .7 \mathrm{mmol})$, potassium carbonate $(4.27$ g. $0.031 \mathrm{~mol})$. chloroacetonitrile $(2 \mathrm{~mL}, 0.032 \mathrm{~mol})$, and sodium iodide $(4.63 \mathrm{~g} .0 .031 \mathrm{~mol})$ in acetone $(125 \mathrm{~mL})$ were stirred and heated under reflux for 7 lurs. The cooled mixture was filtered and the residue was washed with dichloromethane and the product triturated with $\mathrm{MeOH}$ to give $2.8 \mathrm{~g}(50 \%)$ of $\mathbf{2 a} . \mathrm{mp}>290^{\circ} \mathrm{C}$ (decomp.). ${ }^{l} \mathrm{H}$ NMR $\left(\mathrm{CDCl}_{3}\right) \delta 7.12$ and 6.73 (two s. $8 \mathrm{H}, \mathrm{ArH}$ ) 5.56 (s. $2 \mathrm{H}$. $\mathrm{ArOH}$ ), 4.81 (s. $4 \mathrm{H} . \mathrm{OCH}_{2} \mathrm{CN}$ ), 4.22 and 3.45 (a pair of d. $8 \mathrm{H} . \mathrm{ArCH} \mathrm{H}_{2} \mathrm{Ar} J=13.2 \mathrm{~Hz}$ ), 1.33 and 0.88 (two s. $36 \mathrm{H}$, tertbutyl).

$5,11,17,23$-Tetra-tert-butyl-25,27-bis(cyanomethyloxy)26,28-di-methoxycalix[4]arene (2b). To a solution of $1.0 \mathrm{~g}$ 


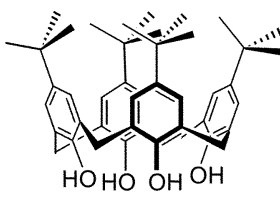

1

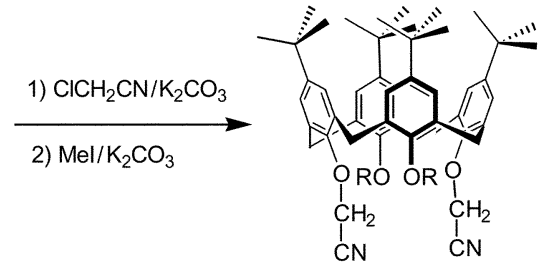

2

$$
\text { a, } \mathrm{R}=\mathrm{H}
$$

b, $\mathrm{R}=\mathrm{CH}_{3}$

$\mid \begin{gathered}\mathrm{LiAlH}_{4} \\ \mathrm{or} \\ \mathrm{BH}_{3}\end{gathered}$

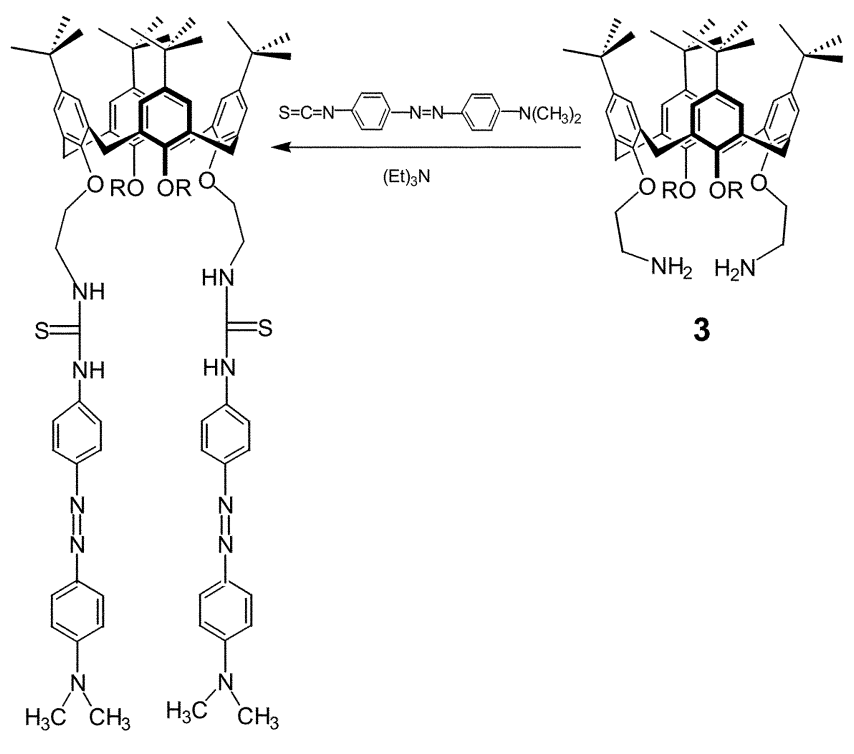

4

Figure 1. Synthesis of jonophores derived from calix[4]arenes.

$(1.38 \mathrm{mmol})$ of $2 \mathrm{a}$ and $0.66 \mathrm{~g}(27.5 \mathrm{mmol})$ of $\mathrm{NaH}$ in $60 \mathrm{~mL}$ of $\mathrm{IHF}$ and $6 \mathrm{~mL}$ of DMF, $5.12 \mathrm{~g}(36.1 \mathrm{mmol})$ of $\mathrm{CH}_{3} \mathrm{l}$ was added, and refluxed for $2 \mathrm{hrs}$. After cooling to room temperature, $10 \mathrm{~mL}$ of $\mathrm{MeOH}$ was added and stirred for 30 min, then acidified with $2 \mathrm{~N} \mathrm{HCl}$ solution. The mixture was extracted by $\mathrm{CHCl}_{3}(2 \times 100 \mathrm{~mL})$. The solvents were removed and the residue was triturated with $\mathrm{MeOH}$ to give $0.79(76 \%)$ of 2 b. mp $231-333^{\circ} \mathrm{C}$. 'H NMR $\left(\mathrm{CDCl}_{3}\right) \delta 7.12$ and $6.50(\mathrm{~s}, 8 \mathrm{H}, \mathrm{ArH}), 4.98\left(\mathrm{~s}, 4 \mathrm{H}, \mathrm{OCH}_{2} \mathrm{CN}\right), 3.82(\mathrm{~s}, 6 \mathrm{H}$, $\mathrm{OCH}_{3}$ ), 4.40 and 3.28 (a pair of d. $8 \mathrm{H}, \mathrm{ArCH}_{2} \mathrm{Ar} J=13.2$ $\mathrm{Hz}), \mathrm{l} .3 \mathrm{l}$ and 0.85 (s, 36H, tert-butyl).

5,1 1,1 7,23-Tetra-tert-butyl-25,27-bis(2-aminocthyloxy)26,28-dihydroxycalix[4]arene (3a). Jo a vigorously stirred solution of compound $2 \mathrm{a}(1.0 \mathrm{~g}, 1.4 \mathrm{mmol})$ in diethylether $(50 \mathrm{~mL})$, a slurry of $\mathrm{LiAlH}_{4}(0.43 \mathrm{~g} .11 .3 \mathrm{mmol})$ was added in portion, and the reaction mixture was refluxed for 5 hrs. Ihen the reaction flask was immersed into an ice-water bath, benzene $(50 \mathrm{~mL})$ and water $(2 \mathrm{~mL})$ added to the flask contents, and an organic layer separated out. The solvent was removed to afford compound $\mathbf{3} \mathbf{a}$ as a white solid $0.98 \mathrm{~g}$ (96\%). mp 143-145 ${ }^{\circ} \mathrm{C}$. 'H NMR (CDCl $) \delta 8.31$ (broad s,
$2 \mathrm{H}, \mathrm{ArOH}$ ), 7.04 and 6.97 (two s, $8 \mathrm{H}, \mathrm{ArH}$ ), 4.24 and 3.43 (a pair of d, $8 \mathrm{H}, \mathrm{ArCH}_{2} \mathrm{Ar} J=12.9 \mathrm{~Hz}$ ), 4.07 (t, $4 \mathrm{H}_{,}-\mathrm{OCH}_{2-}$ ), $3.30\left(\mathrm{t}, 4 \mathrm{H},-\mathrm{CH}_{2} \mathrm{~N}\right.$ ), 1.25 and 1.09 (two s, $36 \mathrm{H}$, tert-butyl).

$5,11,17,23$-Tetra-tert-butyl-25,27-bis(2-aminoethyloxy)26,28-dimethoxycalix|4|arene (3b). A $6 \mathrm{~mL}$ of l $\mathrm{M} \mathrm{BH}_{3} /$ THF solution was added to $0.3 \mathrm{~g}$ of $\mathbf{2 b}$ under nitrogen atmosphere and refluxed for 2 hrs. The solvents were removed and the residue was treated with $10 \mathrm{~mL}$. of $2 \mathrm{~N} \mathrm{HCl}$ and refluxed for $\mathrm{l} \mathrm{h}$. After cooling to room temperature. $10 \% \mathrm{KOH}$ solution was added until the solution became basic, which was then extracted by $\mathrm{CHCl}_{3}(2 \times 40 \mathrm{~mL})$. The solvents were removed and the residue triturated with $\mathrm{MeOH}$ to give $0.163 \mathrm{~g}(54.1 \%)$ of $3 \mathrm{~b}$. $\mathrm{mp}>238^{\circ} \mathrm{C}$, dec. ${ }^{1} \mathrm{H}$ NMR $\left(\mathrm{CDCl}_{3}\right) \delta 7.15$ and $6.53(\mathrm{~s}, 8 \mathrm{H}, \mathrm{ArH}), 4.38(\mathrm{t}, 4 \mathrm{H}$, $\left.\mathrm{OCH}_{2}\right), 3.88\left(\mathrm{~s}, 6 \mathrm{H}, \mathrm{OCH}_{3}\right), 4.21$ and 3.25 (a pair of d. $8 \mathrm{H}$, $\mathrm{ArCH}_{2} \mathrm{Ar} J=12.6 \mathrm{H}$ ) $), 3.52$ (t. $4 \mathrm{H},-\mathrm{CH}_{2} \mathrm{NH}_{2}$ ), 1.33 and 0.82 (s, $36 \mathrm{H}$, tent-butyl).

$5,11,17,23$-Tetra-fert-butyl-25,27-bis|(N,N-dimethylaniline-azo-phenylthioureido)ethyl|oxy-26,28-dihydroxycalix/4|arene (4a). To a $100 \mathrm{mg}(0.137 \mathrm{mmol})$ of compound $3 a$ in chloroform (20 $\mathrm{ml}$ ), $85 \mathrm{mg}$ dimethyl-aniline-a7.phenylisothiocyanate $(0.3 \mathrm{mmol})$ and $30 \mu \mathrm{l},(\mathrm{Et})_{\mathrm{s}} \mathrm{N}(0.274$ mmol) were added and the mixture was stirred overnight under nitrogen atmosphere. At the end of the reaction, 20 $\mathrm{ml}$, of $1 \mathrm{~N} \mathrm{HCl}$ solution were added and stirred vigorously for $20 \mathrm{~min}$. The separated organic layer was removed from the solvent. The crude product was further purified by column chromatography (eluent $n$-hexane : $\mathrm{CHCl}_{3}$ : methanol $=8: 4: 1)$ to give $120 \mathrm{mg}(67 \%)$ of $4 \mathrm{a}$ having an orange color. $\mathrm{mp} 220^{\circ} \mathrm{C}$. ${ }^{1} \mathrm{H}$ NMR $\left(\mathrm{CDCl}_{3}\right) \delta 8.0(\mathrm{t}, 2 \mathrm{H},-\mathrm{NH}) .7 .87$ and 6.78 (two d, $8 \mathrm{H}, \mathrm{ArH}, J=9.3 \mathrm{~Hz}$ ), $7.76(\mathrm{~s}, 2 \mathrm{H},-\mathrm{OH}$ ), 7.58 and 7.20 (a pair of d, $8 \mathrm{H}, \mathrm{ArH}, J=8.7 \mathrm{~Hz}$ ). $7.46(\mathrm{~s} .2 \mathrm{H}$, $-\mathrm{NH}-$ ), 6.88 and 6.74 (two s, $8 \mathrm{H}, \mathrm{ArH}), 4.16$ and $4.01(\mathrm{~m}, 8 \mathrm{H}$, $-\mathrm{OCH}_{2} \mathrm{CH}_{2} \mathrm{NH}-$ ), 3.75 and 3.13 (a pair of $\mathrm{d}, 8 \mathrm{H},-\mathrm{ArCH}_{2} \mathrm{Ar}$ $J=12.3 \mathrm{~Hz}), 3.11\left(\mathrm{~s}, 12 \mathrm{H}_{0}-\mathrm{N}\left(\mathrm{CH}_{3}\right)_{2}\right), 1.23$ and 0.97 (two $s_{n}$ $\left.36 \mathrm{H}_{n}-\mathrm{C}\left(\mathrm{CH}_{3}\right)_{s}\right)$.

$5,11,17,23$-Tetra-tert-buty]-25,27-bis [ $\mathrm{N}, \mathrm{N}$-dimethylaniline-azo-phenylthioureido)ethyl]oxy-26,28-dimethoxycalix|4|arene (4b). lo a $149 \mathrm{mg}(0.95 \mathrm{mmol})$ of compound $3 \mathbf{b}$ in chloroform $(10 \mathrm{~mL}) .121 \mathrm{mg}$ dimethyl-aniline-azophenylisothiocyanate $(0.43 \mathrm{mmol})$ and $54 \mu \mathrm{L}(\mathrm{Et})_{3} \mathrm{~N}(0.39$ mmol) were added and the mixture was stirred overnight under the nitrogen atmosphere. At the end of the reaction, 20 $\mathrm{mL}$ of $1 \mathrm{~N} \mathrm{HCl}$ solution were added, and stirred vigorously for $20 \mathrm{~min}$. The separated organic layer was removed from the solvent. The crude product was further purified by column chromatography (eluent $n$-hexane : $\mathrm{CHCl}_{3}$ : methanol $=6: 3: 1)$ to give $193 \mathrm{mg}(75 \%)$ of $\mathbf{4 b}$ having an orange color. mp $196^{\circ} \mathrm{C}$. 'H NMR (CDCl 3 ) $\delta 10.76$ and 8.75 (two s, $4 \mathrm{H},-\mathrm{NH}$ ), 7.84 and 6.74 (a pair of d. $8 \mathrm{H}, \mathrm{ArH}, J=9 \mathrm{~Hz}$ ), 7.77 and 7.04 (a pair of d, $8 \mathrm{H}, \mathrm{ArH}, J=8.9 \mathrm{~Hz}$ ), 4.04, 3.87. $3.74,3.09$ (broad m, 16H, $-\mathrm{OCH}_{2} \mathrm{CH}_{2}-,-\mathrm{ArCH}_{2} \mathrm{Ar}-$ ), 3.09 (s, 12H, $\left.-\mathrm{N}\left(\mathrm{CH}_{3}\right)_{2}\right), 1.25$ and 0.97 (two s, $36 \mathrm{H}$, tert-butyl).

Preparation of polymeric ion-selective electrodes. The compositions of PVC-based chloride-selective electrodes are summarized in lable 1 . The ionophore, plasticizer, additive and $\mathrm{PVC}$ were dissolved in an appropriate volume of $\mathrm{THF}$ 
Table 1. Compositions and sensitivities of chloride-selective electrodes based on azo-functionalized calix|4|arenes

\begin{tabular}{cccccccc}
\hline no. & $\begin{array}{c}\text { Jonophore } \\
\text { (mg) }\end{array}$ & PVC $^{\alpha z}$ & o.NPOE & DOS & Add & Slope & LOD \\
\hline $\mathrm{m}-1$ & - & 33 & 66 & & $50^{\circ}$ & -46.0 & -2.87 \\
$\mathrm{~m}-2$ & - & 33 & & 66 & $50^{\circ}$ & -44.0 & -3.34 \\
$\mathrm{~m}-3$ & $\mathbf{4 a ( 1 )}$ & 33 & 66 & & 50 & -52.0 & -4.02 \\
$\mathrm{~m}-4$ & $\mathbf{4 a ( 1 )}$ & 33 & & 66 & 50 & -42.5 & -4.02 \\
$\mathrm{~m}-5$ & $\mathbf{4 a ( 1 )}$ & 33 & 66 & & - & -40.0 & -4.33 \\
$\mathrm{~m}-6$ & $\mathbf{4 b ( 1 )}$ & 33 & 66 & & 50 & -30.0 & -2.67 \\
$\mathrm{~m}-7$ & $\mathbf{4 b ( 1 )}$ & 33 & & 66 & 50 & -37.6 & -3.92 \\
\hline
\end{tabular}

"In mg. "mol \% relative to the jonophore. "mol \% relative to the ionophore ta.

and mechanically stirred. All membrane cocktails were cast in glass rings placed on glass plates for conventional ionselective electrodes. Solvent from PVC membrane was allowed to evaporate for more than 24 hours at room temperature. The thickness of the resulting membrane was about $0.3 \mathrm{~mm}$.

Potentiometric measurements. The electrochemical properties of chloride-selective electrodes were investigated in the conventional configuration. Small disks were punched from the cast membranes and mounted in Philips electrode bodies (IS-561). For all electrodes, $0.1 \mathrm{M} \mathrm{KCl}$ was used as an internal filling solution. The external reference electrode was an Orion sleeve-type double-junction $\mathrm{Ag} / \mathrm{AgCl}$ reference electrode (Model 90-02). The electrochemical potential was measured by using Kosentech 16-channel potentiometer (KST101-1) coupled to a computer. The dynamic response curves were produced by adding standard solutions of anions to magnetically stirred $0.05 \mathrm{M}$ [4-(2-hydroxyethyl)-1-piperazineethanesulfonic acid (HГPГS)-l,iOH buffer solutions. The selectivity coefficients were detemined by the separate solution method (SSM). At least three measurements were performed.

\section{Results and Discussion}

An anion ionophore should bind selectively with specific anion, and have kinetically fast exchange, sufficient lipophilicity. Azo-functionalized calix[4]arenes (4a, 4b) as chloride ionophores were synthesized in the present study. The potentiometric responses of $\mathrm{PVC}$ polymeric $\mathrm{Cl}^{-}$-lSEs based on ionophores $\mathbf{4 a}$, or $\mathbf{4 b}$ were examined for several anions in buffer solutions. The $\mathrm{Cl}^{-}$-[SE membrane compositions were optimized to produce the best sensitivity and selectivity toward the chloride anion. The optimization was carried out with variations in the ratio in PVC membrane components, such as PVC, plasticizer, ionophore, additive (IDDMACl), and $\mathrm{THF}$. The polymeric membranes have been investigated to measure the ability of the ionophores to act as neutral carriers in the absence and presence of the ionophore. Electrode membrane containing no specific selective ionophore showed poor response to all anions tested. However, the response of the membranes containing additive ion-exchanger (IDDMACl) and the ionophore gave better

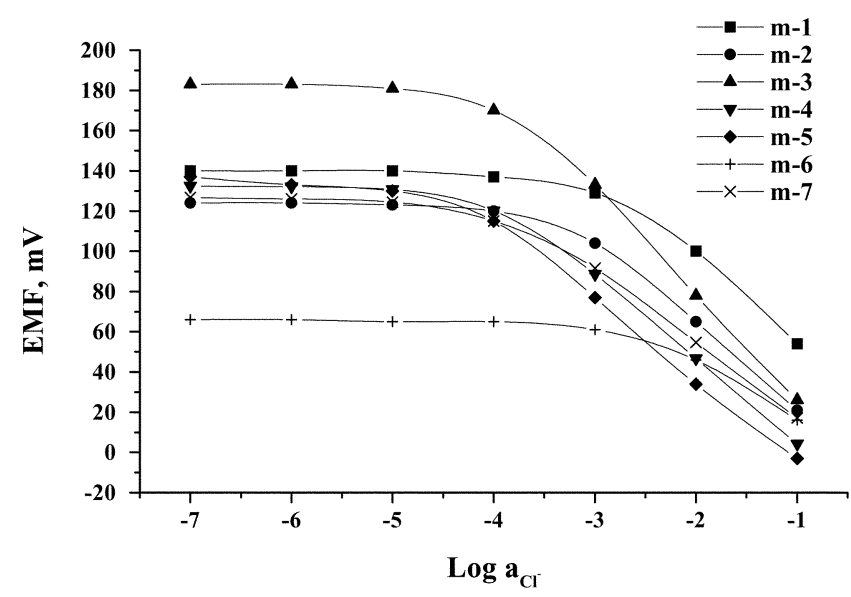

Figure 2. The potentionetric responses of the clloride selective electrodes based on diflerent ionophores and plasticizers.

sensitivity and selectivity than those prepared with only TDDMACl, indicating that the novel ionophore improves sensitivity and selectivity to chloride anion in membrane electrodes. Most of the membranes used in this work contained TDDMACl. The potentiometric response of the membranes was evaluated as to the slope and detection limit(DL) towards chloride anion. The potentiometric responses of PVC polymeric membranes containing azofunctionalized calix[4] arenes $(\mathbf{4 a}, \mathbf{4 b})$ for chloride anionselective electrode were extensively studied in $\mathrm{pH} 7.0$ solutions. The typical composition was $50 \mathrm{~mol} \%$ TDDMACI vs, ionophore, $33 \mathrm{mg}$ PVC, $66 \mathrm{mg}$ plasticizer, and $1 \mathrm{mg}$ ionophore 4a, 4b. Figure 2 shows the potentiometric responses of PVC membrane electrodes prepared with without ionophores, and the potentiometric results for chloride are shown in Table 1. The ISL ( $m-3$ ) based on azofunctionalized calix[4]arene $\mathbf{4 a}$ exhibits a linear stable response over a wide concentration range $\left(1.5 \times 10^{-1}\right.$ $\left.1.0 \times 10^{-1}\right)$ with a slope of $-52.0 \mathrm{mV} /$ decade and a detection limit of $\log \left[\mathrm{Cl}^{-}\right]=-4.02$. Among the membranes prepared from azo-functionalized calix[4]arenes $(4 \mathbf{a}, \mathbf{4 b})$, the azofunctionalized calix[4]arene $4 \mathbf{a}$ gives good sensitivity and sub-Nernstian slope. These results imply that the azo-functionalized calix[4]arene $4 a$ having the appropriate cavity may effectively bind with chloride anion in the polymeric membrane. The responses of the membrane to eleven interfering anions were tested under the determined optimal conditions. Using an electrode based on a quarternary ammonium salt (IDDMACI), the potentiometric response follows the Hofmeister series. 'The selectivity series of the membrane containing ionophore $4 \mathbf{a}$ gives the following as $\mathrm{ClO}_{4}^{-}>$Salicylate $>\mathrm{I}^{-}>\mathrm{SCN}^{-}>\mathrm{Br}^{-}>\mathrm{NO}_{3}^{-}>\mathrm{Cl}^{-}, \mathrm{NO}_{2}^{-}>$ $\mathrm{HSO}_{3}^{-}>\mathrm{HSO}_{4}^{-}>\mathrm{CH}_{3} \mathrm{COO}^{-}>\mathrm{H}_{2} \mathrm{PO}_{4}^{-}$. Compared with an electrode based on a quatemary ammonium salt (IDDMACl), this ionophore-based ISE exibited improved selectivity, responsibility, and detection limit for chloride anion.

It is known that the membrane matrix, i.e. polymer, plasticizer and additive, play crucial roles in the functioning of the membrane electrodes. 'The membranes containing only $\mathrm{PVC}$ and plasticizer (DOS or $o-\mathrm{NPOE}$ ) give a 
Table 2. Selectivity coellicients of various interfering ions for membrane (m-3) electrodes obtained by SSM

\begin{tabular}{|c|c|}
\hline Interfering ion & $\mathrm{K}_{\mathrm{Cl}^{-}, \mathrm{j}}^{\mathrm{por1}}$ \\
\hline $\mathrm{ClO}_{4}$ & 38 \\
\hline Sal & 37 \\
\hline I & 30 \\
\hline $\mathrm{SCN}$ & 5.9 \\
\hline $\mathrm{Br}$ & 3.1 \\
\hline $\mathrm{NO}_{3}$ & 2.9 \\
\hline $\mathrm{NO}_{2}$ & 1.0 \\
\hline $\mathrm{ISO}_{3}$ & $8.1 \cdot 10^{2}$ \\
\hline $\mathrm{ISO}_{3}$ & $1.6 \cdot 10^{2}$ \\
\hline $\mathrm{CII} \mathrm{COO}$ & $1.2 \cdot 10^{2}$ \\
\hline $\mathrm{I}_{2} \mathrm{PO}_{4}$ & $3.3 \cdot 10^{3}$ \\
\hline
\end{tabular}

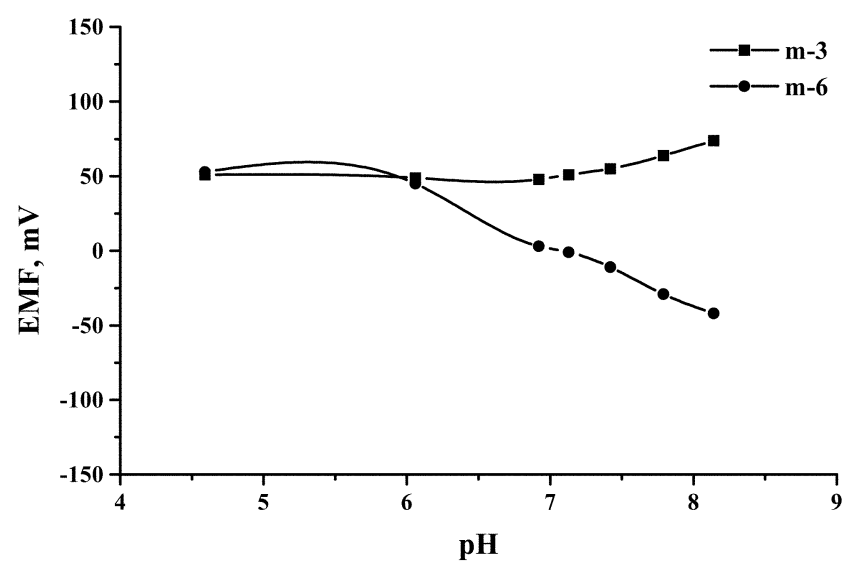

Figure 3. The $\mathrm{pH}$ dependence of potentiomelric responses of $\mathrm{PVC}$ membrane electrodus prepared from azo-functionalized calix|4|arenes $(\mathbf{4 a}, \mathbf{4 b})$ with $0-\mathrm{N} P O E$ as a plasticizer.

substandard potentiometric response. Moreover, as can be seen in Table 1, the membranes containing PVC, plasticizer, and additive show some potentiometric response, but with poor sensitivities. The effect of plasticizers in the presense of ionophores was investigated in PVC polymeric membranes containing l $\mathrm{mg}$ ionophore 4a, 50 mol\% TDDMACl ws. ionophore, $33 \mathrm{mg} P V C$, and $66 \mathrm{mg}$ plasticizer. Based on the results of fig. 2 and lable 1, membranes prepared from 0 NPOE showed the best detection limit, good linear range, and sub-Nernstian slope for chloride anion. Thus, $o-\mathrm{NPOE}$ was chosen as a proper plasticizer for use in the $\mathrm{Cl}^{-}$-ISE membranes. The $\mathrm{pH}$ dependence of potentiometric response was measured in different $\mathrm{pH}$ solutions. Fig. 3 shows the $\mathrm{pH}$ dependence of potentiometric responses of PVC membrane electrodes prepared from azo-functionalized calix[4]arenes (4a. 4b) with $O-N P O E$ as a plasticizer. The membrane electrode of azo-functionalized calix[4]arene 4a is indepedent of the solution $\mathrm{pH}$ used. Thus, $\mathrm{pH} 7.0$ buffer solutions were used in this study. The response time of the ionophore-based membrane electrode ranged from less than $10 \mathrm{sec}$ at all concentrations of chloride ion, and these novel prepared electrodes did not display any hysteric effects. The stability of these membrane electrodes was measured as a function of time. The membranes are stored in $0.05 \mathrm{M}$ HГPES-l.iOH $\mathrm{pH} 7.0$ buffer solutions when not in use. The stability in the polymeric membrane may be dependent upon the lipophilicity of an ionophore, which can result in the ionophore bleeding from the membrane. Since azo-functionalized calix [4]arenes $(\mathbf{4 a}, \mathbf{4 b})$ as ionophores are neutral compounds having high lipophilicity, the membranes based on them should produce slow bleeding of ionophore. After one month, the electrodes were responding at $95 \%$ of the initial response. The prolong lifetime of the membrane as the $\mathrm{Cl}^{-}$ISF: is due to the relatively high lipophilicity of the neutral ionoplores tested in the membrane.

\section{Conclusions}

Azo-functionalized calix[4]arenes (4a, 4b) tested as chloride ionophores were synthesized and used as ionophores for chloride-selective electrode. The IS 5 ( $\mathrm{m}-3$ ) based on azofunctionalized calix[4]arene $4 a$ exhibited a linear stable response over a wide concentration range $\left(1.5 \times 10^{-1}-1.0 \times\right.$ $10^{-1}$ ) with a slope of $-52.0 \mathrm{mV} /$ decade and a detection limit of $\log \left[\mathrm{Cl}^{-}\right]=-4.02$. This ionophore-based ISF : exhibited improved selectivity, responsibility, and detection limit for the chloride anion compared with classical Hofineister series. The membrane electrode was found to be chemically and physically stable, and gave steady potential response within 10 seconds with high reproducibility. The long lifetime of the membrane as the chloride-IST: is due to the relatively high lipophilicity of azo-functionalized calix[4]arenes as neutral ionophores in the membrane.

Acknowledgment. This work was supported by Korea Research Foundation Grant (KRF-2002).

\section{References}

1. Dietrich. B. Pare Appl Chem. 1993, 65, 1457.

2. Atwood. LE L.: I Jolman. K. I.: Steed. I. W. Chen. Comm. 1996. 1401.

3. Oka. S.: Sibazahi. Y.: Tahara. S. Anal. Chen. 1981. 53.588.

4. Park. S. B.: Matuszewski. W.: Meyerhott. M. E.: Liu. Y. H.: Kadish, K. M. Electromalysis 1991, 3,909.

5. Wuthier, U.: Pham, II. V: 7.und. R.: Welti. D.: Funk, R, J. J.: Be\%egh. A.: Ammann. D.: Pretsch. 1.: Simon. W. Anal. Chem. 1984. 56.535 .

6. Rothmaies: M.: Simon. W. Indl (him. Acta 1993. 271.135.

7. Ozawa. S.: Miyagi. H.: Shibata. Y.: Oki. N.: Kunitake. T.: Keller. W. Г. Anat (hem 1996,68,4149.

8. Wegmann, D.: Weiss, I1.: Ammann, D.: Morf, W. F.: Pretsch, F.: Sugahara. K.: Simon. W. Witrochim Acta 1984. /I. 1.

9. Kimura. K.: Matsute. M.: Yokoyama. M. Int Chim Atat 1991. 252.41.

10. Kim. W.: Chung. S.: Park. S. B.: Lec. S. C.: Kim. C.: Sung. D. D. Anal. Chem. 1997,69,95.

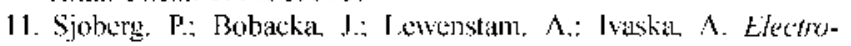
andusis 1999. /1.821.

12. Yoon. I. J.: Shin. J. H.: Paeng. I. R.: Nam. H.: Cha. G. S.: Paeng. K.-J. Anat ('him . Acta 1998. 367. 175.

13. Malinowska. E.: Nicdziolka. J.: Meyerhoft. M. E. Anat. (him. fcte 2001, 432.67

14. Volf. R.: Shishkanova T. V.: Matejkis, P.: Ilamplova M.: Kral, V. 
Anal. Ghim. Acta 1999.381. 197.

15. Gutsche. C. D. Calixarenes Renisifed. Royal Society of Chemistry: Cambridge, UK. 1998.

16. Viens. J.: Bohmer V. Calikarenes a Lersatile Chass of Macrocychic Componds: Kluwer: Dordrecht The Netherlands. 1990.

17. Kang. S. O.: Oh. J. M.: Yang. Y. S.: Chun. J. C.: Jeon. S.: Nam. K. C. Bull. Konem (Chem. Soc. 2002, 23, 145.
18. Jeong. H. S.: Choi. E. M.: Kang. S. O.: Nam. K. C.: Jeon. S. J. Electroanal. Chem. 2000. 485.154.

19. Nam. K. C: Kang, S. O.: Jeong. H. S.: Jeon, S. Tetrahedhon Letters $1999,40,7343$.

20. Jeon, S.: Yeo, H; Jeong. H. S.: Oh, J. M: Nam. K. C. Electroanalysis 2003 . in press. 